Supplement of Biogeosciences, 15, 6537-6557, 2018

https://doi.org/10.5194/bg-15-6537-2018-supplement

(C) Author(s) 2018. This work is distributed under

the Creative Commons Attribution 4.0 License.

(c) (1)

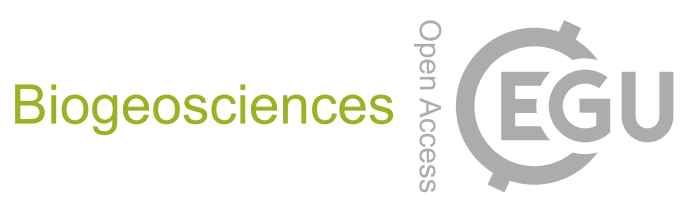

Supplement of

\title{
Carbon and nitrogen turnover in the Arctic deep sea: in situ benthic com- munity response to diatom and coccolithophorid phytodetritus
}

Ulrike Braeckman et al.

Correspondence to: Ulrike Braeckman (ulrike.braeckman@ugent.be)

The copyright of individual parts of the supplement might differ from the CC BY 4.0 License. 


\section{Supplementary Information}
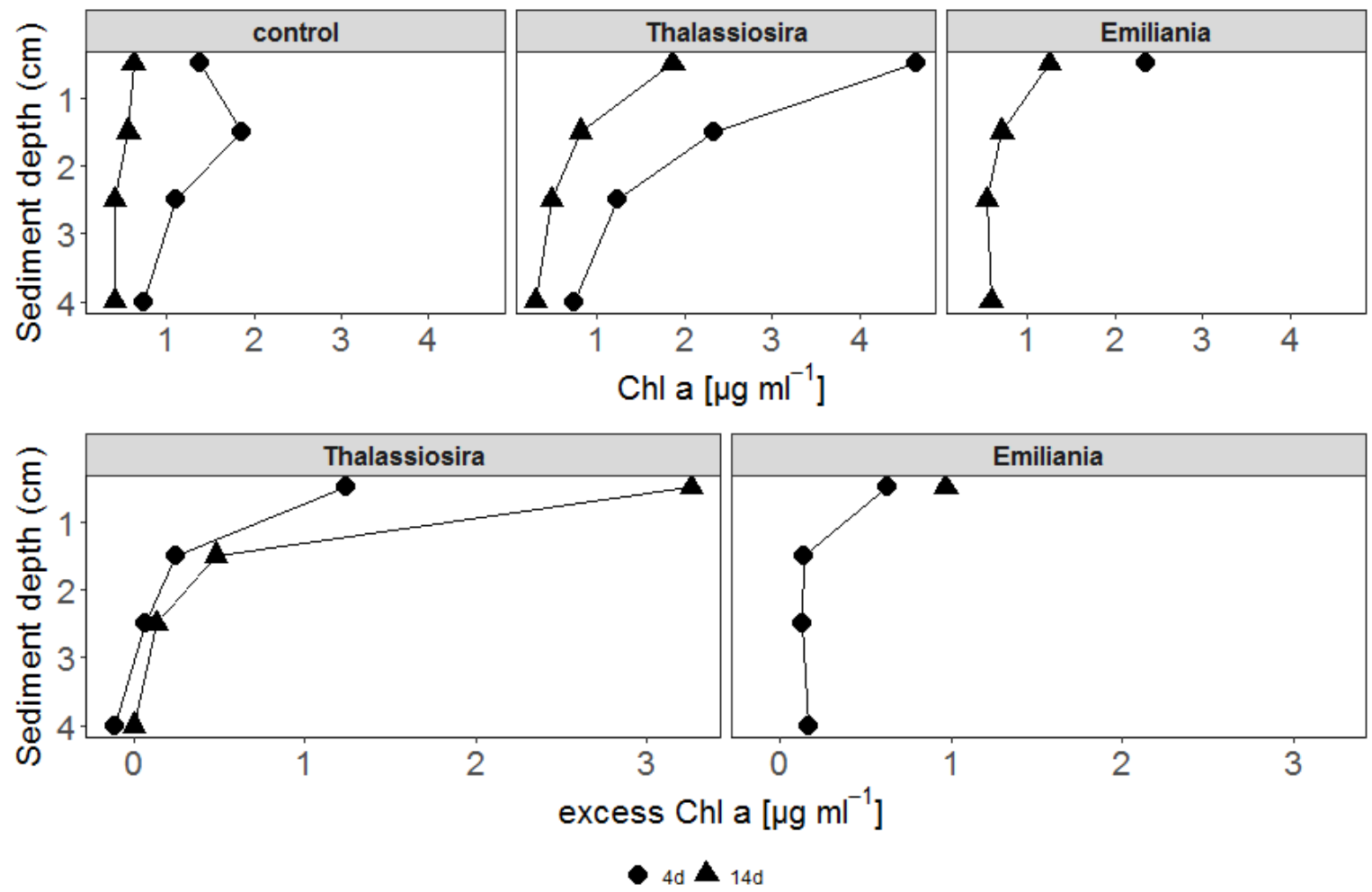

Figure S1: Chlorophyll- $a$ concentration in the sediment (upper panel: absolute concentrations and lower panel: excess concentrations compared to control). In the $4 \mathrm{~d}$ Emiliania experiment, only the top $\mathrm{cm}$ of sediment could be retrieved and sampled. 

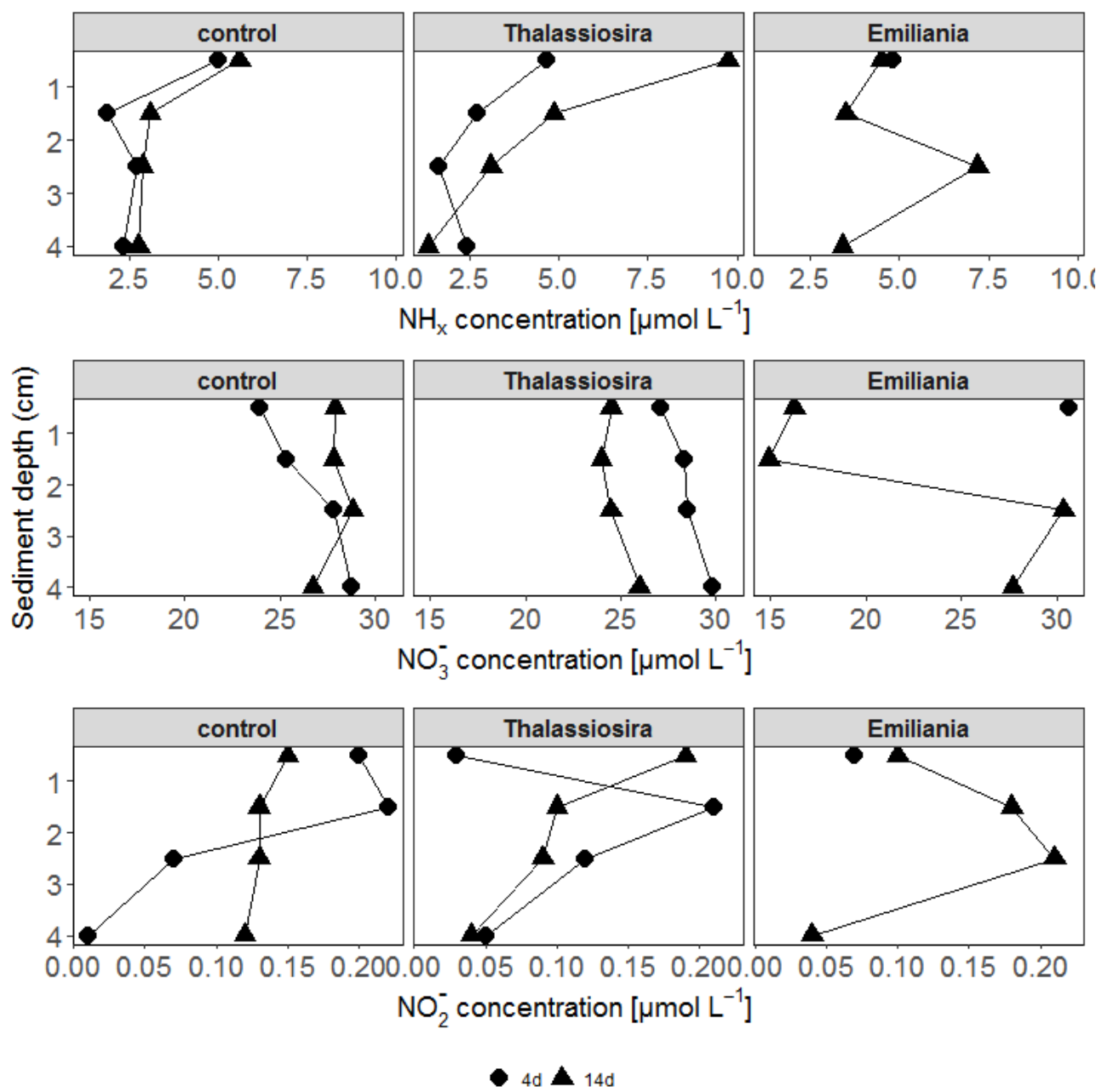

Figure S2: Concentrations of total $\mathrm{NH}_{\mathrm{x}}, \mathrm{NO}_{3}{ }^{-}$and $\mathrm{NO}_{2}^{-}$in the pore water of all experiments. In the $4 \mathrm{~d}$ Emiliania experiment, only the top $\mathrm{cm}$ of sediment could be retrieved and sampled. 


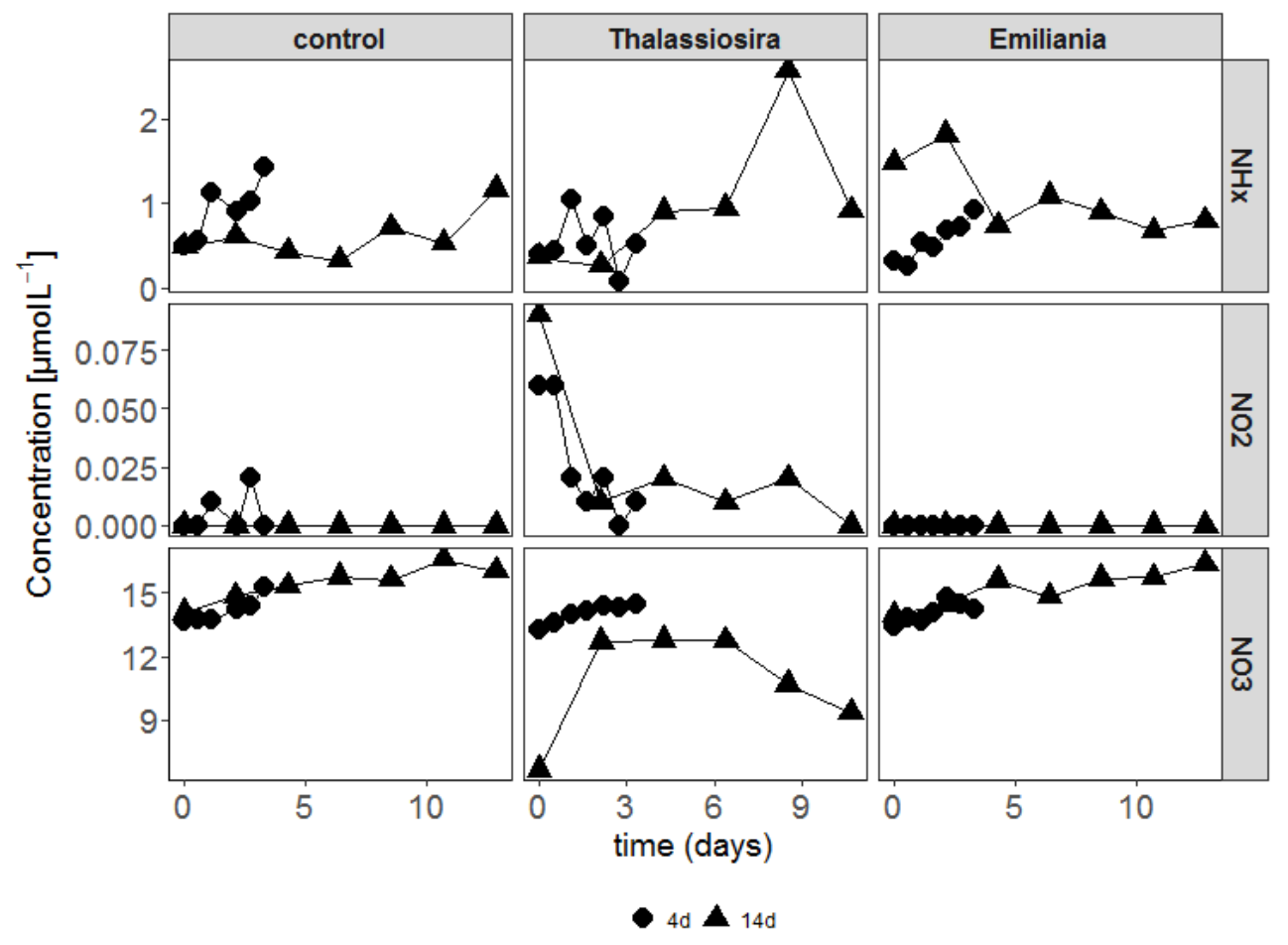

Figure S3: Concentrations of total $\mathrm{NH}_{4}, \mathrm{NO}_{3}^{-}$and $\mathrm{NO}_{2}{ }^{-}$in the overlying water of all experiments.

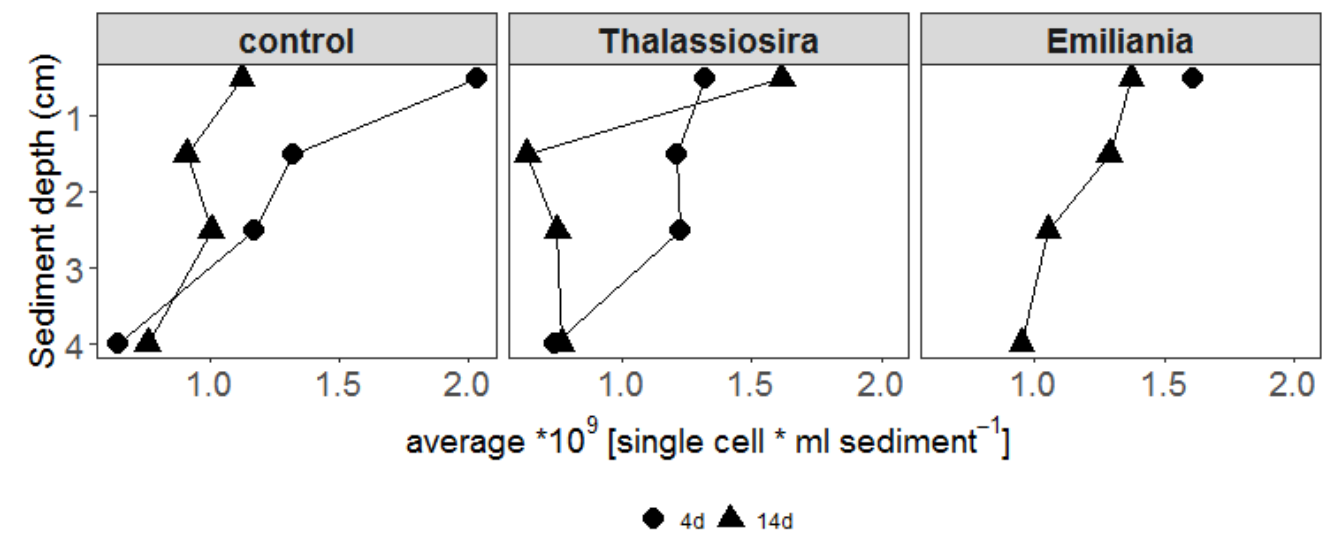

Figure S4: Microbial abundances in the sediment in the $4 \mathrm{~d}$ control, Emiliania and Thalassiosira experiments. In the $4 \mathrm{~d}$ Emiliania experiment, only the top $\mathrm{cm}$ of sediment could be retrieved and sampled. 


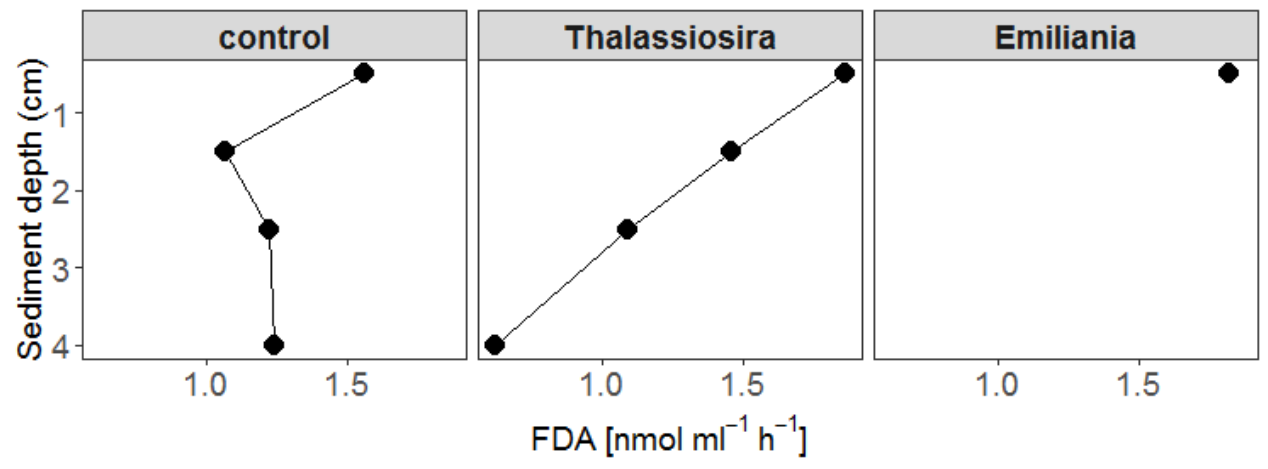

Figure S5: Bacterial esterase enzymatic activity (FDA) in the sediment in the $4 \mathrm{~d}$ control, Emiliania and Thalassiosira experiments. In the $4 \mathrm{~d}$ Emiliania experiment, only the top $\mathrm{cm}$ of sediment could be retrieved and sampled. 


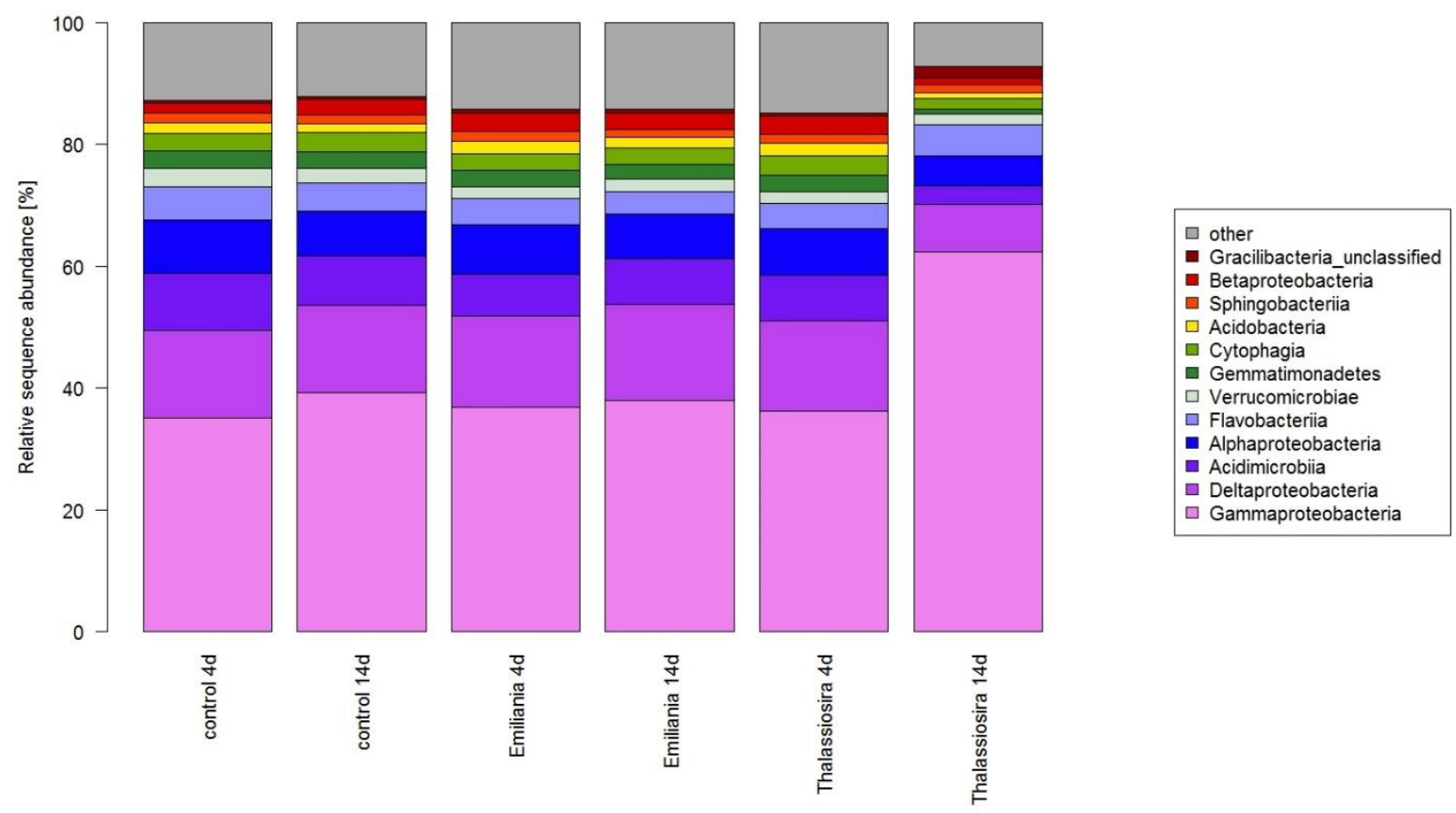

Figure S6: Dominant classes of the total bacterial community in the different experiments.

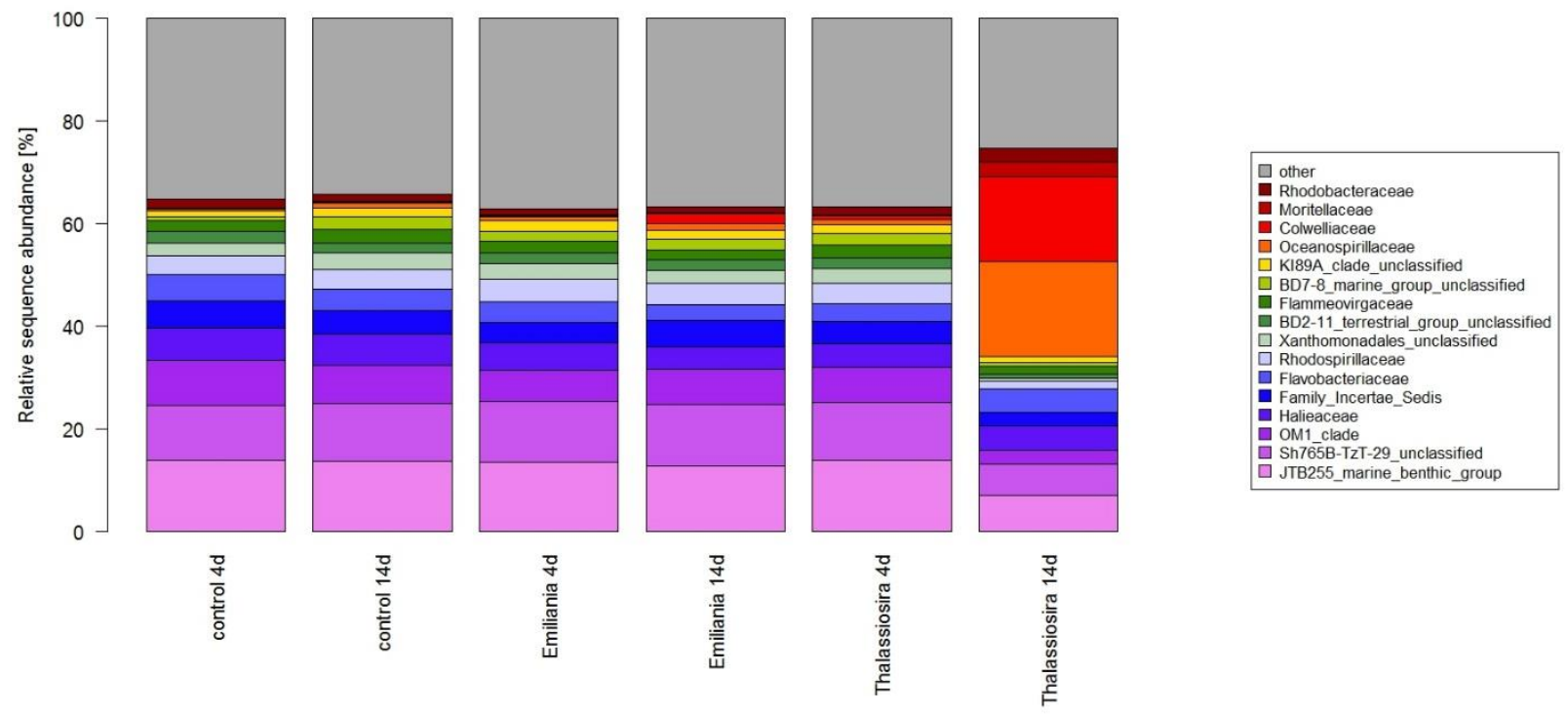

Figure S7: Dominant families of the total bacterial communities in the different experiments. 


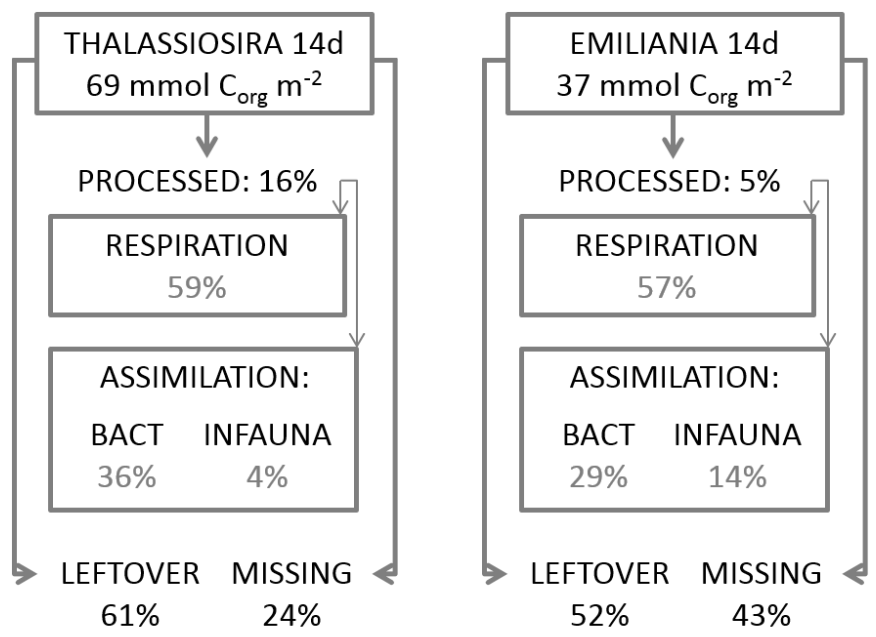

Figure S8: Carbon inventory of the $14 \mathrm{~d}$ experiments, divided over processed pools (Respiration as the summed DIC production in overlying water and pore water and assimilation by bacteria and infauna). Leftovers of the non-processed phytodetritus in the sediment and the missing carbon to close the budget are presented at the bottom. Respiration and assimilation given in grey numbers to represent percentages of the total processed pool. 
Table S1: Observed numbers of bacterial OTUs (nOTU), chao1 richness estimates (chao1) and inverse Simpson indices (invSimpson) for the different experiments/treatments/samples.

\begin{tabular}{lccc}
\hline & nOTU & chao1 & invSimpson \\
\hline control 4 d & 863 & 1675 & 151 \\
control 14 d & 937 & 1948 & 162 \\
Emiliania 4 d & 989 & 2126 & 194 \\
Emiliania 14 d & 1063 & 2360 & 208 \\
Thalassiosira 4 d & 1010 & 2204 & 191 \\
Thalassiosira 14 d & 726 & 1494 & 69 \\
\hline
\end{tabular}

Table S2: Overview of measured ${ }^{15} \mathrm{~N}^{-\mathrm{NO}_{\mathrm{x}}}{ }^{-}$accumulation in the overlying water, the calculated labelling fraction of pore water $\mathrm{NH}_{4}{ }^{+}$and the algae-derived $\mathrm{NO}_{\mathrm{x}}{ }^{-}$ accumulation in the overlying water.

\begin{tabular}{|c|c|c|c|c|}
\hline & Thalassiosira $4 \mathrm{~d}$ & Emiliania 4 d & Thalassiosira $14 \mathrm{~d}$ & Emiliania 14 d \\
\hline${ }^{15} \mathrm{~N}-\mathrm{NO}{ }_{\mathrm{x}}^{-}$accumulation $\left[\mu \mathrm{mol} \mathrm{m}^{-2} \mathrm{~d}^{-1}\right]$ & 0.56 & 0.00 & 0.38 & 0.35 \\
\hline Labelling fraction $\left({ }^{15} \mathrm{~N}-\mathrm{NH}_{4}+/\right.$ total $\left.\mathrm{NH}_{4}{ }^{+}\right)$in the pore water & 0.14 & 0.04 & 0.47 & 0.18 \\
\hline Algae derived NO${ }^{-}$accumulation $\left[\mu \mathrm{mol} \mathrm{m}^{-2} \mathrm{~d}^{-1}\right]$ & 4.00 & 0.00 & 0.74 & 2.11 \\
\hline
\end{tabular}

